\title{
Determination of microbial quality of tsire offered for sale at Hadejia Local Government Area, Jigawa state
}

${ }^{1}$ Umar, A. M., ${ }^{2}$ Muhammad, B. F., ${ }^{1}$ Muhammad, Y., ${ }^{3}$ Mohammed, A. and ${ }^{4}$ Abdurrahman, S. L.

${ }^{I}$ Department of Animal Health and Production, Binyaminu Usman Polytechnic, Hadejia, Jigawa State.

${ }^{2}$ Department of Animal Science, Bayero University, Kano.

${ }^{3}$ Department of Animal Health and Production, Federal Polytechnic Bauchi

${ }^{4}$ Department of Animal Science, Federal University Dutse.

Corresponding author: auw.umar@gmail.com;

$+2348164727548 ;+2348027374654$

Abstract

$\overline{\text { Microorganisms grow on meat causing visual, textural and organoleptic changes when they }}$ release metabolites. A lot of factors affect the growth of microorganisms on meat, which include temperature, $p H$, water availability, presence of nutrients, gaseous requirement and atmosphere of storage. Microbial quality of raw meat and tsire sold at retail outlets from Yayari, Yankoli and Matsaro of Hadejia metropolis, Jigawa State were evaluated. Three samples from each outlet were collected fortnightly into sterile plastic bags, stored at $4{ }^{\circ} \mathrm{C}$ in ice chest filled with ice and transported immediately to the laboratory for Total Viable Count (TVC), Total Coliform Count (TCC), Total Staphylococcus Count (TCS) and Total Fungal Count (TFC) analyses using Nutrient Agar, Mac Conkey Agar, Mannitol Salt Agar and Potato Dextrose Agar, respectively. They were incubated at $37{ }^{\circ} \mathrm{C}$ for 24 hours except for the detection of fungi, which was incubated at $25{ }^{\circ} \mathrm{C}$ for 5 days. Tsire samples collected from Matsaro had the highest TVC $\left(6.0 \times 10^{4}\right)$ while that from Yankoli had the highest TCS $\left(4.0 \times 10^{2}\right)$. The study concluded that tsire sold at Hadejia Local Government Area was safe for consumption, due to its less microbial load.

Keywords: Microbial load, Tsire, sale, Jigawa

\section{Introduction}

Tsire is a roasted or smoked beef or other boneless animal meat. It is rich in protein, mineral (zinc, selenium and phosphorus) and is also a good source of niacin, vitamin B6 (pyridoxine) and iron (Koffi-Nevry et al., 2011). It is one of the most streetvended meat products in Nigeria and subSaharan Africa (Abdullahi et al., 2006). The preparation processes of tsire involve defatting and slicing the meat on a slab or table, after which it is staked into sticks, spiced and roasted for about twenty (20) minutes, thereafter, the products is spiced again and briefly reheated for about two (2) minutes. It is then displayed for marketing on table tops or trays where it can be streetvended (Edema et al., 2008). Tsire preparation process in Nigeria lacks standard or hygienic quality control therefore there is increase in food safety risks (Odusole and Akinyanju, 2003; Inyang et al., 2005; Adzitey et al., 2010). Notwithstanding the major role meat plays in our meals, it can also serve as a rich medium of growth for harmful microorganisms. Meat infected with microorganisms is the cause of many foodborne diseases (WHO, 1997). The sources of these pathogenic microorganisms may be the animals themselves or from outside the surroundings where these animals are kept as well as the way they are processed after slaughtering can also result in contamination with microorganisms (Adeyemo, 2002). Meat infected with 


\section{Determination of microbial quality of tsire}

microorganisms is normally poor in quality (Mukhopadhyay, 2009). The study is aimed to examine the microbial quality of tsire offered for sale at Hadejia Local Government Area of Jigawa state.

\section{Materials and methods}

This study was carried out in Hadejia Metropolitan of Jigawa State (figure 1). Hadejia lies between latitude $12^{\circ} 27^{\prime} 2.18^{\prime \prime}$ $\mathrm{N}$ and longitude $10^{\circ} 2^{\prime} 25.47^{\prime \prime} \mathrm{E}$ (Umar and Abdullahi, 2017). Hadejia Local Government Area possesses palatable grasses (Andropogan gayanus, Cyanodon dactylum and Pennisetum pedicelatum) and legumes (Centrosema pubescens and Stylosanthes hamata) with crops residues such as sorghum stover, millet stalks, rice straws, cowpea haulms, ground nut hay and agro-byproducts which include wheat offal, cotton seed cake, ground nut cake and cereal bran. Major livestock slaughtered include cattle, sheep, goat and camel. Table 1 presented the monthly break down of livestock slaughtered at Hadejia Abattoir. Information from PPA (2019) showed that on daily basis, average of 400 chickens (improved and indigenous), 70 guinea fowls, 40 pigeons, 10 ducks and 1 turkey were slaughtered.

Table 1: Break down of Livestock Slaughtered at Hadejia Abattoir

\begin{tabular}{lllll}
\hline Month & \multicolumn{4}{c}{ Livestock } \\
\cline { 2 - 5 } & Cattle & Sheep & Goat & Camel \\
\hline January & 220 & 120 & 382 & 191 \\
February & 261 & 131 & 566 & 161 \\
March & 118 & 110 & 486 & 184 \\
\hline
\end{tabular}

Source: Meat Inspector, Hadejia Abattoir: 2019

The study area has an annual rainfall ranging from $700-800 \mathrm{~mm}$ accompanied by strong wind. The temperature of the area ranged from 31 to $40^{\circ} \mathrm{C}$. Olofin (1987) stated that the combination of rainfall and temperature is controlled by the movement of the Inter Tropical Discontinuity (ITD) which results in four seasons in the year, viz: Dry and Cool Season from December to February (Bazara), Dry and Hot Season from March to May (Rani), Wet and Warm Season from June to November (Damina) and a season of decreasing rain fall and fallen temperature from October to November (Kaka). Triplicate raw meat and tsire samples sold in three different locations namely Yayari, Yankoli and Matsaro were randomly selected. A total of fifty-four meat samples (Table 2) were collected aseptically with the help of sterilized knives.

Table 2: Total number of samples collected for assessment of microbial contamination

\begin{tabular}{lcc}
\hline S/N & Type of meat & Number of Samples \\
\hline 1 & Raw & 27 \\
2 & Tsire & 27 \\
& Total & 54 \\
\hline
\end{tabular}

Freshly slaughtered beef and tsire samples from the various outlets were collected fortnightly from 3rd to 17th April, 2018 into sterile plastic bags, stored at $4{ }^{\circ} \mathrm{C}$ in ice chest filled with ice and transported immediately to the laboratory for Total Viable Count (TVC), Total Coliform Count
(TCC), Total Staphylococcus Count (TCS) and Total Fungal Count (TFC) analyses using Nutrient Agar, Mac Conkey Agar, Mannitol Salt Agar and Potato Dextrose Agar, respectively and incubated at $37{ }^{\circ} \mathrm{C}$ for 24 hours except for the detection of fungi, which was incubated at $25{ }^{\circ} \mathrm{C}$ for 5 days. 


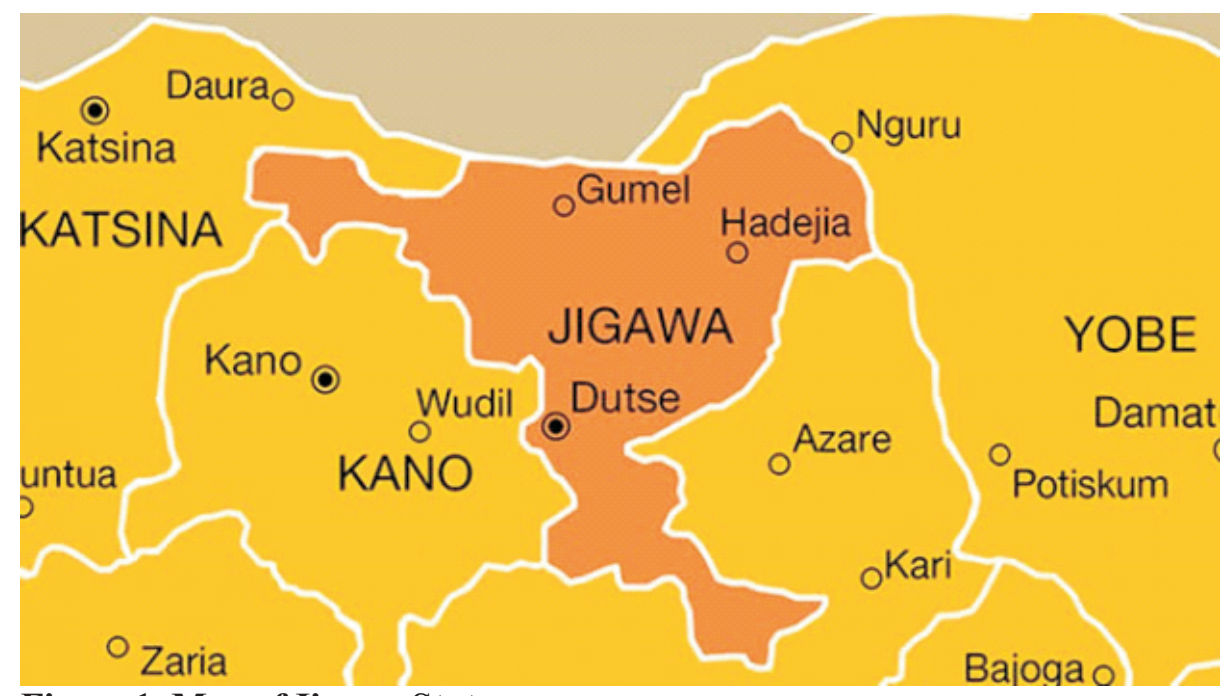

Figure 1: Map of Jigawa State

Tsire is a boneless lean meat which is cut into pieces and sliced with a sharp knife, staked on a wooden/iron stick and heavily dusted with a mixture of spices made up of groundnut cake paste, red pepper, seasoning, salt, ground ginger, garlic, ground nut oil and other aromatic spices. The staked meat is roasted around a glowing charcoal fire (figure 2) as described by Abubakar et al. (2014).

Fresh meat

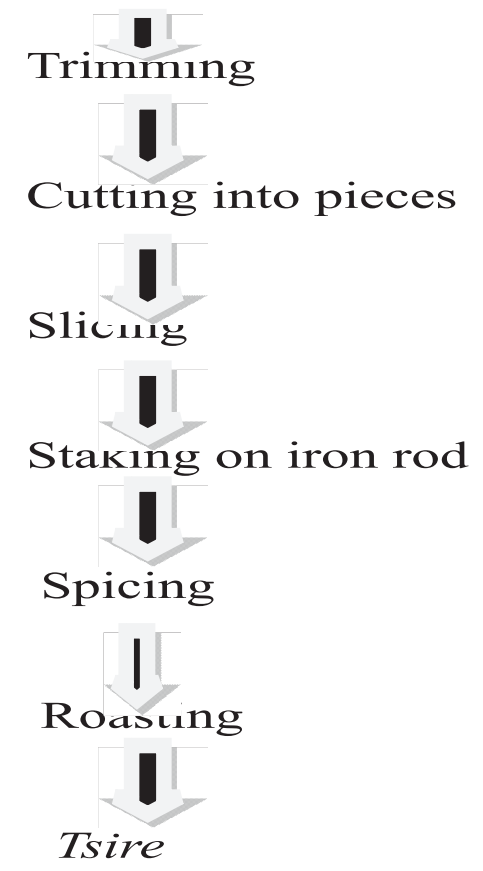

Figure 2: Procedure for Tsire Preparation: Abubakar et al. (2014) 


\section{Determination of microbial quality of tsire}

Tsire piece from each sample was removed from the skewers and mashed in a sterile laboratory mortar and pestle. $1 \mathrm{~g}$ of the mashed sample was weighed and then aseptically introduced into $9 \mathrm{ml}$ of sterile distilled water, properly shaken and sieved before a twofold dilution was performed. The samples were inoculated aseptically using streak technique and the plates were read for growth of organisms. The counts for each plate were expressed as colony forming unit (cfu/g) of the suspension that
Is

Colony forming unit $/ \mathrm{g}=$

Number of colony counted $\mathrm{x}$ Reciprocal of dilution factor Volume of sample inoculated

\section{Results and discussions}

The microbial load of raw meat was presented in Table 3. Highest TVC $\left(9.0 \times 10^{6} \mathrm{cfu} / \mathrm{g}\right)$ and TCC $\left(5.0 \times 10^{6} \mathrm{cfu} / \mathrm{g}\right)$ were reported at Matsaro while highest TSC $\left(3.8 \times 10^{3} \mathrm{cfu} / \mathrm{g}\right)$ and TFC $\left(4.2 \times 10^{2} \mathrm{cfu} / \mathrm{g}\right)$ were reported at Yayari.

Table 3: Microbial load of raw meat (cfu/g)

\begin{tabular}{|c|c|c|c|c|}
\hline Sample Location & $\begin{array}{l}\text { Total viable count } \\
\left(\mathrm{x} 10^{6}\right)\end{array}$ & $\begin{array}{l}\text { Total coliform } \\
\text { count }\left(\times 10^{6}\right)\end{array}$ & $\begin{array}{l}\text { Total } \\
\text { staphylococcus } \\
\text { count }\left(\mathrm{x} 10^{3}\right)\end{array}$ & $\begin{array}{l}\text { Total fungal count } \\
\left(\mathrm{x} 10^{2}\right)\end{array}$ \\
\hline Yayari & 7.5 & 4.5 & 3.8 & 4.2 \\
\hline Yankoli & 3.5 & 3.0 & 2.4 & 1.3 \\
\hline Matsaro & 9.0 & 5.0 & 1.0 & 3.5 \\
\hline
\end{tabular}

The microbial load of tsire was presented in Table 4. No growth of TCC and TSC were reported at Matsaro, equally no growth of TSC and TFC were reported at Yayari. On the other hand, Matsaro had the highest TVC $\left(6.0 \times 10^{4}\right)$ while Yankoli had the highest TSC $\left(4.0 \times 10^{2}\right)$. The various meat outlets have different hygienic levels as far as transportation, handling and processing is concerned. This might have accounted for the variations in TVC, TCC, TSC and TFC as shown in Tables 3 and 4. This is in line with the work of Ruban and Fairoze (2011) and Obeng et al. (2013) who attributed the higher microbial levels from non-sophisticated outlets compared to sophisticated ones. This may be due to unhygienic handling of meat right from slaughtering, butchering equipment, handling, transportation and processing (Warris, 2010).

Table 4: Microbial load of tsire (cfu/g)

\begin{tabular}{lllll}
\hline $\begin{array}{l}\text { Sample } \\
\text { Location }\end{array}$ & $\begin{array}{l}\text { Total viable } \\
\text { count }\end{array}$ & $\begin{array}{l}\text { Total coliform } \\
\text { count }\end{array}$ & $\begin{array}{l}\text { Total staphylococcus } \\
\text { count }\end{array}$ & Total fungal count \\
\hline Yayari & $1.8 \times 10^{4}$ & $1.0 \times 10^{2}$ & $0.0 \times 10^{1}$ & $0.0 \times 10^{1}$ \\
Yankoli & $2.6 \times 10^{5}$ & $1.7 \times 10^{3}$ & $4.0 \times 10^{2}$ & $2.0 \times 10^{2}$ \\
Matsaro & $6.0 \times 10^{4}$ & $0.0 \times 10^{1}$ & $0.0 \times 10^{1}$ & $1.0 \times 10^{2}$ \\
\hline
\end{tabular}

Microorganisms grow on meat causing visual, textural and organoleptic changes when they release metabolites (Walter and Kundin, 2002). A lot of factors affect the growth of microorganisms on meat, which include temperature, $\mathrm{pH}$, water availability, presence of nutrients, gaseous requirement and atmosphere of storage (Nester et al. 2001). The possible sources of contamination are through slaughtering of sick animals, washing the meat with dirty water, handling by butchers, contamination by flies, processing close to sewage or refuse dumps environment, addition of contaminated spices, transportation and use of contaminated equipment such as knives and other utensils (Igyor and Uma, 2005) as well as the packaging materials (Enem and Onyekwodiri, 2009). High microbial loads lead to spoilage of foods that have not been properly stored (Nester et al., 2001). 
species (Aspergillus niger, Aspergillus fumigatus, Rhizophus nigricans and Hansenula anomala) after seven days storage of meat products at ambient temperature. Other workers such as Ologhobo et al. (2010) and Salihu et al. (2010) have also reported that meat products sold in Nigeria were contaminated with various species of bacteria and fungi. The microbial load obtained in the current study $\left(1.1-7.0 \times 10^{4} \mathrm{cfu} / \mathrm{g}\right)$ could be compared to what had been reported locally: $2.88 \times 10^{2}-9.49 \times 10^{3}$ (cfu/g) by Abubakar et al. (2014) for Dambun-Nama, $7.0 \times 10^{2}-1.71 \times 10^{4} \mathrm{cfu} / \mathrm{g}$ by Uzeh et al.(2006) for tsire suya, $3.3 \times 10^{4} \mathrm{cfu} / \mathrm{g}$ for processed ready to eat beef by Ologhobo et al. (2010), $7.0 \times 10^{3}-2.22 \times 10^{5} \mathrm{cfu} / \mathrm{g}$ for ready to eat suya by Edema et al.(2008), 3.7 x $10^{5}-2.4 \times 10^{6} \mathrm{cfu} / \mathrm{g}$ by Inyang et al. (2005), $7.4 \times 10^{4} \mathrm{cfu} / \mathrm{g}$ by Chukwu and Imodiboh, (2009) and $8 \times 10^{5} \mathrm{cfu} / \mathrm{g}$ by Shamsuddeen and Oyeyi, (2008). All these fell within the safe limits of $10^{7} \mathrm{cfu} / \mathrm{g}$ specified for meat products by the ICMSF (1978). On the contrary Salihu et al. (2010) obtained total mesophilic aerobic bacteria count of $4.5 \times 10^{9} \mathrm{cfu} / \mathrm{g}$ on traditionally prepared Dambun -Nama sold in Sokoto and concluded that the product (DambunNama) was unsafe and constitutes a food safety risk to the numerous ever-increasing consumers. It can therefore be said that meat sold in the study areas were not spoiled. Nevertheless, the isolation of Staphylococcus spp. is worrying because certain strains of this bacterium cause foodborne infections. Staphylococcus spp. infections can be contacted through consumption of contaminated chevon and mutton (Adzitey et al., 2010). It is an important cause of gastroenteritis. Staphylococcus spp. can be present on the skin of humans and animals and can be transmitted from person to product through unhygienic practices (Postgate, 2000). Staphylococcus spp. cause infections such as arthritis, black pox, boil, bronchitis, carbuncle, cystitis, endocarditis, meningitis, osteomyelitis, pneumonia and scalded skin (Stuart, 2005). To ensure good microbial quality of meat products, proper hygiene must be ascertained to guarantee safety from infection and to promote quality assurance.

Meat contamination can be achieved if aseptic techniques are employed during the production of meat (Field, 2002). Processing operations such as heating, boiling, filtration, freezing, irradiation of finished product, addition of condiment and condition of storage affect both bacterial and fungal loads (Igyor and Uma, 2005).

\section{Conclusion and recommendation}

The study concluded that tsire sold at Hadejia Local Government Area was safe for consumption, due to its less microbial load. It is recommended that meat sellers and handlers should as often as possible be enlightened on proper animal handling, hygienic slaughter, proper meat transportation, sanitation of utensils, equipment and proper storage of meat. This would help reduce the rate of meat contamination.

\section{References}

Abubakar, M. M., Bube, M. M., Adegbola, T. A. and Oyawoye, E. O. 2011. Processing and Evaluation of Dambu, Tsire and Balangu from Non-Ruminant Animals. ACT-Biotechnology Research Communications, 1:149155.

Abubakar, M. M., Bube, M. M., Adegbola, T. A. and Oyawoye, E. O. 2014. Assessment of Four Meat Products (Kilishi, Tsire, Dambu and Balangu) in Bauchi Metropolis. ACT-Biotechnology Research Communications, 1:140148. 


\section{Determination of microbial quality of tsire}

Abdullahi, I. O., Umoh, V. J. and Galadima, M. 2006. Hazzards Associated with Kilishi Preparation in Zaria, Nigeria. Journal of Microbiology, 18(2):328-345.

Adzitey, F., Teye, G. A., Ayim, A. G., and Addy, S. 2010. Microbial Quality of Chevon and Mutton sold in Tamale Metropolis of Northern Ghana. Journal of Applied Sciences and Environmental Management. 14(4):53-55.

Adeyemo, O. K. 2002. Unhygienic Operation of a City Abattoir in South Western Nigeria: Environmental Implication. African Journal of Environmental Assessment and Management. 4(1):23-28.

Chukwu, O. and Imodiboh, L. I. 2009. Influence of Storage Conditions on Shelf-Life of Dried Beef Product (Kilishi), World J. Agric. Sci. 5:3439.

Edema, M. O., Osho, A. T. and Diala, C. I. 2008. Evaluation of Microbial Hazard Associated with Processing of Suya (A Grilled Meat Product). Sci. Res. Essays 3(12):621-626.

Enem, S. I. and Onyekwodiri, E. O. 2009. Evaluation of Bacterial Contamination of Suya at Nsukka, Enugu State, Nigeria. Animal Prod. Res. Adv. 5(1): 4665-4721.

Field, R. A. 2002. Enteric and food-borne illnesses. Advanced Food Research. 27:28-35.

ICMSF, 1978. International Commission of Microbiological Standards for Foods. Micro-Organisms in Foods 2. Sampling for Microbial Analysis. Principles and Specific Applications. University of Toronto Press, Toronto.

Igyor, M. A. and Uma, E. N. 2005. Bacterial Quality of Smoked Meat
Product (Suya). Nigeria Food Journal. 23: 233-242.

Inyang, C. U., Igyor, M. A. and Uma, E. N. 2005. Bacterial Quality of a Smoked Meat Product (Suya). Nigerian Food Journal, 23:239242.

Koffi-Nevry, R., Koussemon, M. and Coulibaly，S. O. 2011 . Bacteriological Quality of Beef Offered for Retail Sale in Cote D'ivoire. American Journal of Food Technology. 6(9):835-842.

Mukhopadhyay, H. K., Pillai, R. M., Pal, U. K. and Ajay, V. J. 2009. Microbial Quality of Fresh Chevon and Beef in Retail Outlets of Pondicherry Tamilnadu. Journal of Veterinary and Animal Sciences. 5(1):33-36.

Nester, E. W., Aderson, D. G., Roberts, C. E., Pearsall, N. N. and Nester, M. T. 2001. Microbiology; A Human Perspective. $3^{\text {rd }}$ Edition. McGraw Hill Company, U.S.A.,822-809.

Obeng, A. K., Johnson, F. S. and Appenteng, S. O. 2013. Microbial Quality of Fresh Meat from Retail Outlets in Tolon and Kumbungu Districts of the Northern Region of Ghana. International Journal of Science and Technology. 2(6):424428

Odusole, K. A. and Akinyanju, O. O. 2003. Red Suya Syndrome - Acute Intravascular Ie Adminstration and Control. Consum. Saf. Bull. 2(2):20-24.

Olofin, E.A. 1987. Some Aspect of Physical Geography of the Northern Region and Related Human Responses. Bayero University, Press. Kano.pp.1-15

Ologhobo, A. D., Omojola, A. B., Ofongo, S. T., Moiforay, S. and Jibir, M. 2010. Safety of Street Vended Meat Products - Chicken and Beef Suya. 
African Journal of Biotechnology, 9:4091-4095.

Postgate, J. R. 2000. Microbes and Man. Oxford, UK; New York: Cambridge University Press. p. 373.

PPA, 2019. Poultry Processors Association, Hadejia Local Government Area, Jigawa State, Nigeria.

Ruban, S. W. and Fairoze, N. 2011. Effect of Processing Conditions on Microbiological Quality of Market Poultry Meats in Bangalore, India. Journal of Animal and Veterinary Advances. 10(2):88-191.

Salihu, M. D., Junaidu, A. U., Magaji, A. A., Aliyu, R. M. Y., Shittu, A. and I b r a h i m, M . A . 2010 . Bacteriological Quantity of Traditionally Prepared Fried Ground Beef (Dambun-Nama) in Sokoto, Nigeria. Advance Journal of Food Science and Technology, 2:145-147.

Shamsuddeen, U. and T .I. Oyeyi 2008. Survey on the Possible Microbiological Hazards and Critical Control Points during the Production of Tsire at Fagge L.G.A., Kano, Nigeria . International J. Pure and Appl. Sci. 2:6-10.

Stuart, H. 2005. Essential Microbiology.
The University of Glamorgan, UK; John Wiley and Sons, Ltd.

Umar, A. M. and Abdullahi, H. I. 2017. Chemical Composition of Balangu offered for sale at Hadejia Local Government Area of Jigawa State. Semi-Arid Journal of Academic Research and Development. 1(1):64-69.

Uzeh, R. E., Ohenhen, R. E. and Adeniji, O. O. 2006 . Microbial Contamination of Tsire-Suya-a Nigerian Meat Product. Pak. J. Nutr.; 5 (5):458-460.

Walter, C. W. Kundin, R. B. 2002. Faecal Contamination of Meat and Meat Products. Food Preservation Journal 70: 88-92.

Warriss, P. D. 2010. Meat Science: An Introductory Text. CAB International, Cambridge University Press, Cambridge, UK. 2nd Edition. pp.77-84.

WHO, 1997. World Health Organisation Statistics Quarterly. Food Safety and Foodborne Diseases. 50(1/2).

Received: $20^{\text {th }}$ November, 2019 Accepted: $26^{\text {th }}$ February, 2020 